\title{
$O$ gênero videoclipe sob um olhar intersemiótico
}

\author{
Keity Cassiana Seco BRUNING *
}

(UNOPAR/UEL)

Resumo: Este trabalho objetiva analisar a projeção significativa e discursiva do videoclipe, gênero textual sincrético formado por três planos de expressão: o linguístico, o imagético e o melódico. Para isso, será utilizada a semiótica greimasiana, fundamentação teórica que tem como principal metodologia o percurso gerativo de sentido, composto por diferentes níveis: discursivo, narrativo e fundamental. Também se fará uso, para investigar a melodia, da semiótica da canção, de Luiz Tatit. Busca-se, portanto, observar o processo de produção e veiculação dos sentidos em um texto híbrido, para verificar como a dialogicidade existente entre as diversas linguagens pode reforçar o fazer persuasivo de um texto. Palavras-chave: Texto sincrético; Percurso significativo; Fazer persuasivo.

Abstract: This study aims to analyze meaning and discourse projections in videoclips. This text genre is formed by three expression plans: verbal, visual and melodic. This research will use the Greimasian semiotic theory, whose main methodoly is the generative route of meaning, consisting of different levels: discursive, narrative and fundamental. In order to investigate the melody, this work will also use the semiotics of the song by Luiz Tatit. Therefore, this research observes the process of generation

\footnotetext{
* Doutoranda em Estudos da Linguagem na Universidade Estadual de Londrina. Atua como professora no ensino superior (UNOPAR), e também na rede pública de ensino (SEED-PR). Contato: keytiss@yahoo.com.br.
} 
and transmission of meanings in videoclips in order to see how the several types of language, when mixed, can increase the persuasive force in a text.

Key-words: Mixed text; Meaning route; Persuasive force.

\section{Introdução}

Surgido com o advento da TV e divulgado em maior escala com a informatização, o gênero textual sincrético videoclipe faz parte do cotidiano de muitas sociedades. Afirma-se isto ao levar em consideração o vasto campo dos textos virtuais veiculados mundialmente, hoje, pela internet, os quais são geralmente constituídos por múltiplas linguagens amalgamadas.

Estes novos gêneros textuais são oriundos de uma época marcada por infinitas e contínuas transformações, que vão desde as infraestruturas econômicas e políticas (globalização), passam pelas estruturas socioculturais como a arte, a religião, a ciência, os costumes (mundialização) e chegam até a educação (multiletramento). Diante dessas mudanças, acredita-se ser este um momento promissor para a criação e o desenvolvimento de novas técnicas e materiais pedagógicos que permitam suprir a atual carência metodológica de gêneros midiáticos como a novela, a canção e o videoclipe, entre outros.

Por tudo isso, busca-se analisar como os sentidos são produzidos e veiculados pelo videoclipe - gênero textual híbrido e midiático - por meio da semiótica greimasiana, que considera todos os planos de expressão como sendo repletos de conteúdo significativo. Estes são vistos como produtos humanos e ideológicos sendo modalizados segundo determinada posição axiológica.

Apresenta-se, primeiramente, a análise do conteúdo verbal; em seguida, focaliza-se o plano de expressão imagético e, ao final, os sentidos "contagiantes" do plano de expressão melódico. 


\section{A Semiótica e a Semiótica da Canção}

A partir da revolução industrial e, posteriormente, com a evolução tecnológica na transmissão de mensagens, surgiu a necessidade de desenvolver uma teoria que estudasse todos os tipos de linguagens, com seus sentidos subjacentes. Para isto desenvolveu-se a teoria semiótica, uma com vertente americana (Pierce) e outra européia (Greimas), que têm como corpus de estudo todos os tipos de textos (além dos verbais), formados pelos mais diversos códigos. Sobre este assunto, Barros (2003, p. 8) explica:

[...] o objeto de estudo da semiótica é apenas o texto verbal ou lingüístico? [...] pode ser tanto um texto lingüístico, indiferentemente oral ou escrito [...] quanto um texto visual ou gestual - uma aquarela, uma gravura, uma dança - ou, mais freqüentemente, um texto sincrético de mais de uma expressão - uma história em quadrinhos, um filme, uma canção popular.

Importa salientar que a fundamentação teórica de base utilizada nesta pesquisa é a semiótica greimasiana, que tem como método de estudo o percurso gerativo de sentido. Este contempla três níveis de análise: o Fundamental, o Narrativo e o Discursivo, que vai desde um patamar mais abstrato e simples até o mais concreto e complexo. Cada um deles possui semântica e sintaxe próprias, que permitem observar a gênese e a projeção dos sentidos sob vários ângulos. Tal método, em seu formato tradicional, de cunho mais estruturalista, permite que o leitor reconstitua, de modo coerente e interligado, o sentido global de qualquer texto.

Nessa vertente, a semiótica procura chegar ao eixo semântico embrionário dos textos, ou melhor, seus significados universais (vida/morte, liberdade/opressão, cultura/natureza etc.), que devem ser apreendidos em qualquer época e/ou circunstância. Isto porque, segundo esta ótica, os sentidos essenciais encontram-se no interior textual, independente de seu referente extratextual. 
Esse modelo de leitura tem um valor imensurável para o ensino de linguagem, já que sistematiza o processo didático da leitura na escola de um modo conciso, visível e organizado, permitindo que o aluno de qualquer nível consiga desvelar os significados textuais, com suas estratégias argumentativas, de maneira prática e segura. Inicialmente este esquema de leitura precisa ser mediado pelo professor e, gradativamente, o aluno irá internalizá-lo, tornando-se um sujeito cada vez mais autônomo e reflexivo. Este sujeito, segundo Coquet, é o "lugar em que o irrefletido é compreendido e conquistado pela reflexão" (apud BERTRAND, 2003, p. 263).

Com o amadurecimento científico da semiótica, A. J. Greimas, seu fundador, sentiu a necessidade de ampliá-la. Juntamente com Fontanille, o autor percebeu que, além dos elementos cognitivos, seria necessário considerar também o lado passional e mais opaco dos sentidos, visíveis principalmente nos textos literários, como na poesia. De acordo com os estudiosos,

As considerações sobre a natureza dos estados e, mais particularmente, sobre sua instabilidade, unidas a uma reflexão mais geral sobre o estado do mundo, levam, pois, a interrogar sobre a concepção cognitiva da significação que a discretiza e a torna 'compreensível', não há lugar para a instauração de um horizonte de tensões mal esboçadas que, embora se situando num aquém do sentido do 'ser', permitiria dar conta das manifestações 'ondulatórias' insólitas reconhecidas no discurso. (GREIMAS; FONTANILLE, 1993, p. 15)

Greimas apresenta a importância de mostrar, nas pesquisas textuais, as paixões que modalizam os sujeitos. Tais emoções são determinadas pela sua relação com um objeto valorizado. Este valor, dado pelo sujeito ao objeto, seria influenciado pela cultura de uma sociedade, na qual ele se encontra inserido. Portanto, a valorização acontece tanto no âmbito cognitivo (mais individual e consciente) quanto no sensível (mais coletivo e inconsciente). Essa valorização 
semântico-passional (de um sujeito pelo seu Ov? - aqui, talvez, seja necessário explicitar OV, determinado culturalmente) é muito perceptível nas canções, pois "a música fala ao mesmo tempo ao horizonte da sociedade e ao vértice subjetivo de cada um [...] ela ensaia e antecipa aquelas transformações que estão se dando, que vão se dar, ou que deveriam se dar, na sociedade" (WISNIK, 2006, p. 13).

Além desse arcabouço epistemológico, recorre-se ainda aos três parâmetros de análise pertencentes à semiótica da canção: a Tematização, a Figurativização e a Passionalização. O primeiro "É a vigência da ação. É a redução da duração e da freqüência" (TATIT, 2002, p. 11). Já a figurativização corresponde às partes da canção em que "imperam as leis da articulação lingüísticas, de modo que compreendemos o que é dito pelos mesmos recursos utilizados no colóquio" (TATIT, 2002, p. 21). Todos eles são organizados segundo os critérios de tempo e espaço da sonoridade cancionista, sem desmembrar a letra da melodia que a acompanha. Tatit explica, ainda, que o estilo Passional "é um estado interior afetivo, compatibiliza-se com as tensões decorrentes da ampliação da freqüência e duração. Como se a tensão psíquica correspondesse à tensão acústica e fisiológica de sustentação de uma vogal" (TATIT, 1998, p. 103).

Também fazem parte da investigação do Jingle aqui estudado as concepções referentes à teoria da música tonal e a harmonia funcional, como: cadências harmônicas de acordes, arranjos, estilo de acompanhamento, tipos de instrumentos, interpretação vocal, qualidades básicas da música etc., porquanto, "o sistema tonal estabelece uma sintaxe que rege os movimentos de acúmulo e dissolução de tensão à medida que a música se desenvolve" (DIETRICH, 2003, p. 25).

Dessa forma, o estudo semiótico do videoclipe "História de um Mamute" parte dos e enfatiza os significados presentes no conteúdo do verbal e, posteriormente, verifica o plano da imagem e o da melodia, de uma forma comparativa e intersemiótica. 


\section{Os Sentidos do Conteúdo Verbal Desvelados pela Semiótica ${ }^{1}$}

Obra: História de um Mamute

Letra e melodia: Elbando 2004

Um mamute pequenino queria voar

Tentava e tentava e não podia voar

Uma pombinha, sua amiga, tentou ajudar

E do quinto andar fez ele pular

- O que aconteceu?

Merda o mamute virou merda (2x)

Um mamute pequenino queria fumar

Tentava e tentava e não podia fumar

Um cachorro, seu amigo, tentou ajudar

E quinhentos cigarrinhos fez ele fumar

- O que aconteceu?

Câncer, o mamute teve câncer (2x)

Um mamute pequenino queria beber

Tentava e tentava e não podia beber

Um urso, seu amigo, tentou resolver

E seis litros de Whisky fez ele beber

- O que aconteceu?

Cirrose, no mamute deu cirrose (2x)

Um mamute pequenino queria transar

Tentava e tentava e não podia transar

Um jegue, seu amigo, tentou ajudar

E com cem prostitutas fez ele transar

1 O videoclipe "História de um Mamute" encontra-se disponível em: <http:// www.ochent.com.br/maurilio/mamute/ Mamute_Portugues.htm>. 
- O que aconteceu?

AIDS, o mamute pegou AIDS (2x)

Um mamute pequenino queria se drogar

Tentava e tentava e não podia se drogar

Um gato, seu amigo, tentou ajudar

E cinquenta carreirinhas fez ele cheirar

- O que aconteceu?

Overdose, um mamute com overdose (2x)

- E agora o que aconteceu?

Morreu o mamute morreu

Morreu o mamute se fu...

Morreu o mamute morreu

Morreu o mamute se fu...

Deu!

Ao observar o título do clipe, "História de um Mamute", nota-se que o autor não nomeia este animal, o qual também vem acompanhado pelo artigo indefinido - um. Isto denota a generalização ou universalização, tanto do personagem como das ações realizadas por ele no decorrer do texto.

A narração verbal é realizada por meio de uma fábula em verso, portanto, muitas informações estão implícitas, contendo temas "escondidos" atrás de figuras, necessitando, por isso, do fazer interpretativo do leitor para que ele consiga abstrair todas as "lições" desse texto.

Assim, no nível discursivo, a história se apresenta quase que inteiramente em debreagem enunciva (ele, lá, então), o que demonstra um narrador onisciente e onipresente, que narra um fato vivido por outro sujeito (ele), num tempo não determinado (então/passado) e ocorridos em outro espaço (distante do narrador e de seu narratário). Tal afirmação está pautada na ausência de advérbios de tempo (indeterminação temporal), presença constante 
dos verbos no pretérito perfeito e imperfeito - podia, tentava, tentou, fer, aconteceu, virou - e do pronome pessoal do caso reto - ele mostrando a vOz do narrador em terceira pessoa - Um mamute pequenino queria voar. Esse tipo de sintaxe discursiva quer convencer o interlocutor de que a história é fictícia, mas sua verdade (moral da história) é genérica e imutável, ou seja, o narrador é aquele que transmite uma informação inquestionável (de senso comum), característica própria das fábulas e provérbios.

É interessante notar que, algumas vezes, ocorre uma embreagem enunciativa, em que o narrador dialoga com um suposto narratário. Este representa a voz do ouvinte da canção (eu, aqui, agora), passando a idéia de referência e ancoragem - $O$ que aconteceu?

Este tipo de projeção enunciativa causa o efeito de aproximação entre locutor (narrador) e interlocutor (leitor). Parece que ambos estão conversando pessoalmente, em um mesmo local e num mesmo momento, isto é, o interlocutor (leitor) tem a nítida impressão de estar escutando o narrador contar a história presencialmente.

Essa estrutura se repete em todos os trechos, os quais são independentes entre si, mas, ao mesmo tempo, se interligam, formando um todo global e significativo. Nestes, o sujeito operador mamute se relaciona com seus "amigos" (astutos e adultos), sujeitos destinadores, os quais não pertencem à sua família (sempre ausente). Estes animais levam o filhote ingênuo e solitário a realizar uma série de ações.

O pequeno mamute está à procura do objeto de valor "aventura" e fortes emoções, pressuposto por meio da sequência das seguintes verbos - voar, fumar, beber, transar, se drogar. Destaca-se que o voar pode ser inferido como um esporte radical, praticado geralmente por jovens e adolescentes (escaladas, rachas, asa delta etc.). Todas as suas atitudes denotam a busca do sujeito operador (mamute) por algo diferente, novo, emocionante e, aparentemente prazeroso. Desse modo, o sujeito operador (mamute) quer este OV (aventura), mas, inicialmente, não possui o poder e o saber para realizar as performances - voar, fumar, beber, transar, se drogar 
(Ovs modais) - as quais possibilitariam que ele entrasse em conjunção com o seu OV descritivo: a aventura.

Ressalta-se que todos os cinco trechos da história são tematicamente idênticos, posto que todos possuem os mesmos conceitos subjacentes, sendo modificados apenas figurativamente (mudam as figuras, entretanto as idéias permanecem).

Os sujeitos destinadores - pomba, cachorro, urso, jegue, gato todos aparentemente mais velhos dão o poder e o saber ao mamute, para que ele execute tais ações e consiga seu OV (aventura).

$\mathrm{O}$ texto mostra que os manipuladores conseguem facilmente persuadir o mamute a realizar as ações propostas (fazem o mamute fazer algo). Os animais são considerados verdadeiros amigos pelo mamute que acredita neles e realiza as performances propostas.

Entretanto, logo após as performances acima, ocorrem algumas transformações no físico do mamute, que sofre algumas sanções, consequências das ações ou vícios adquiridos - virou merda, teve câncer, teve cirrose, teve AIDS, tomon uma overdose e morreu. O julgamento e os castigos foram dados pelo próprio corpo do mamute (sujeito julgador), que o julga negativamente e de forma pragmática (perda da vida). Seu organismo não aguenta a intensa exposição às substâncias insalubres e sucumbe.

É possível perceber, sob uma perspectiva axiológica (dentro de nossa cultura), que o mamute doou um OV maior (sua própria vida) para entrar em conjunção com um OV menor, efêmero e destrutivo (aventura).

No nível discursivo, percebe-se que o enunciador usa os substantivos - história e mamute, com um "tom" de ironia, já que as metáforas não estão relacionadas com seres e temas arqueológicos, mas representam uma "espécie" moderna, inserida num contexto temático real: o adolescente ou "jovem humano". Este age, muitas vezes, de modo quase irracional, sem pensar ou se preocupar nas consequências de alguns de seus atos. Assim, o texto apresenta, já no seu início, um estilo crítico e satírico, principalmente, quando se refere à inocência e ingenuidade do pequeno mamute. Este pode ser inferido como sendo o representante do adolescente solitário - um, que busca adrenalina - queria voar, fortes emoções e aceitação social - seu amigo, etc. 
Outras palavras também comprovam a imaturidade do mamute, como o adjetivo diminutivo - pequenino - os verbos tentava, não podia - evidenciando sua dependência dos mais velhos. A locução verbal - queria voar - representando um desejo utópico, para um animal com suas características físicas (anseios típicos de adolescentes).

Importa lembrar que o cantor enfatiza, por meio da sonoridade vocal, a sua ironia na expressão - seu amigo - já que fica evidente, no término de cada trecho, que os outros animais não estavam realmente preocupados com a saúde e a vida do mamute. Tal expressão é utilizada repetidamente, ao longo do texto, para salientar a imagem transmitida pelos animais ao mamute, isto é, a palavra amigo traduz o ethos transmitido pelos bichos. Este é constituído pelos temas: intimidade, docilidade, simpatia, prestatividade e disponibilidade. Esta composição pode ser vista pelas figuras dos animais, escolhidos para representar os papéis sociais de traficante, cafetão etc. - pomba, cachorro, urso (de pelúcia), jegue, gato, - a maioria são animais domésticos muito queridos e próximos das crianças (como alguns "amigos íntimos da família", que muitas vezes são mais perigosos que pessoas estranhas e distantes).

A textualidade mostra que o ser destes bichos desvela-se diferente de seu parecer, porquanto o mamute fica doente e morre. Eles parecem ser seus amigos, ajudando o mamute a fazer e ter tudo que ele queria só que não o alertaram sobre os perigos e os riscos que suas ações e os OVs almejados poderiam lhe trazer. Estes também se mostram falsos quando não aparecem ajudando o mamute a se curar das doenças.

A grande quantidade de produtos ingerida pelo mamute é outro fator importante, sendo evidenciado por hipérboles como quinhentos cigarrinhos, cem prostitutas, cinquenta carreirinhas representando vícios contínuos, que causam a morte prematura. A expressão - e do quinto andar fez ele pular - remetendo a déia que ele, na sua ânsia impensada de querer voar - queria voar - pulou de sua vida juvenil, caindo para a morte súbita no chão. 
A conjunção aditiva $-e-$ também representa o exagero no consumo, bem como a repetição das várias performances inconsequentes do mamute, o qual sempre se dava mal, mas nunca aprendia com os erros. O mamute não é descrito como esperto, que sabe e pode mudar de atitude e preservar sua vida. Isto é reforçado pela expressão - fez ele - onde todos conseguem persuadilo facilmente.

Na parte final aparece a última e fatal sanção do mamute: a morte. Esta aparece numa cadência de sanções - morreu - e pela gíria muito comum entre os adolescentes - fudeu - destacando a última sílaba - deu. Estas palavras remetem ao significado do verbo dar no pretérito perfeito "deu", semiotizando uma jovem vida entregue à morte. Lembra também o vocativo - Deus! - fazendo um apelo para que este cuide da alma do pequeno mamute, já que do corpo o jovem não soube cuidar.

O texto é predominantemente figurativo e possui, em seu interior, a seguinte sequência temática: inocência, insatisfação, busca, vulnerabilidade, ousadia, dependência, exagero, insalubridade e morte.

A partir dos temas descritos acima chega-se à oposição semântica: virtude $\mathrm{x}$ vício, em que o sujeito se encontra em estado inicial eufórico (vivo) terminando em estado de disforia (morte) em sensibilização negativa. Para o enunciador o OV seria a vida, proporcionada pela virtude e, paradigmaticamente, os vícios retiram este OV dos adolescentes aventureiros, que se aproximam dos vícios. Tem-se assim a sintaxe fundamental abaixo, que semiotiza as relações de contrariedade entre dois termos opostos:

\section{Virtude — não virtude — Vícios}

Esta oposição semântica pode também ser vista por meio do quadrado semiótico: 

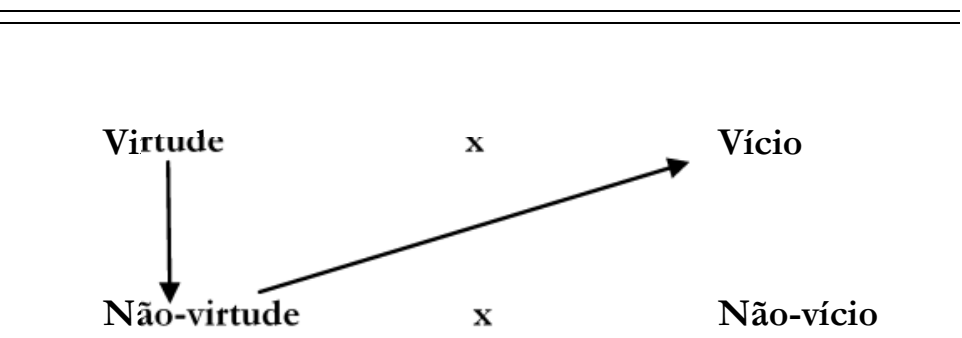

(quadrado semiótico)

\section{Os Sentidos Enfatizados pela Linguagem Imagética}

Logo abaixo estão as principais imagens do videoclipe História de um Mamute, analisadas a seguir.

\section{Imagens: Rick}
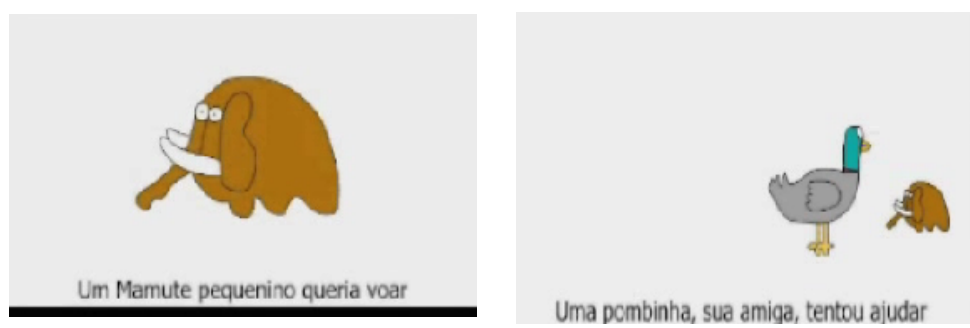

Uma pombinha, sua amiga, tentou ajudar
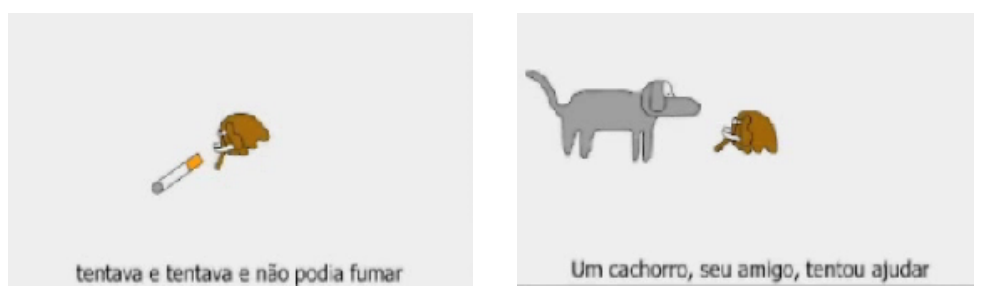

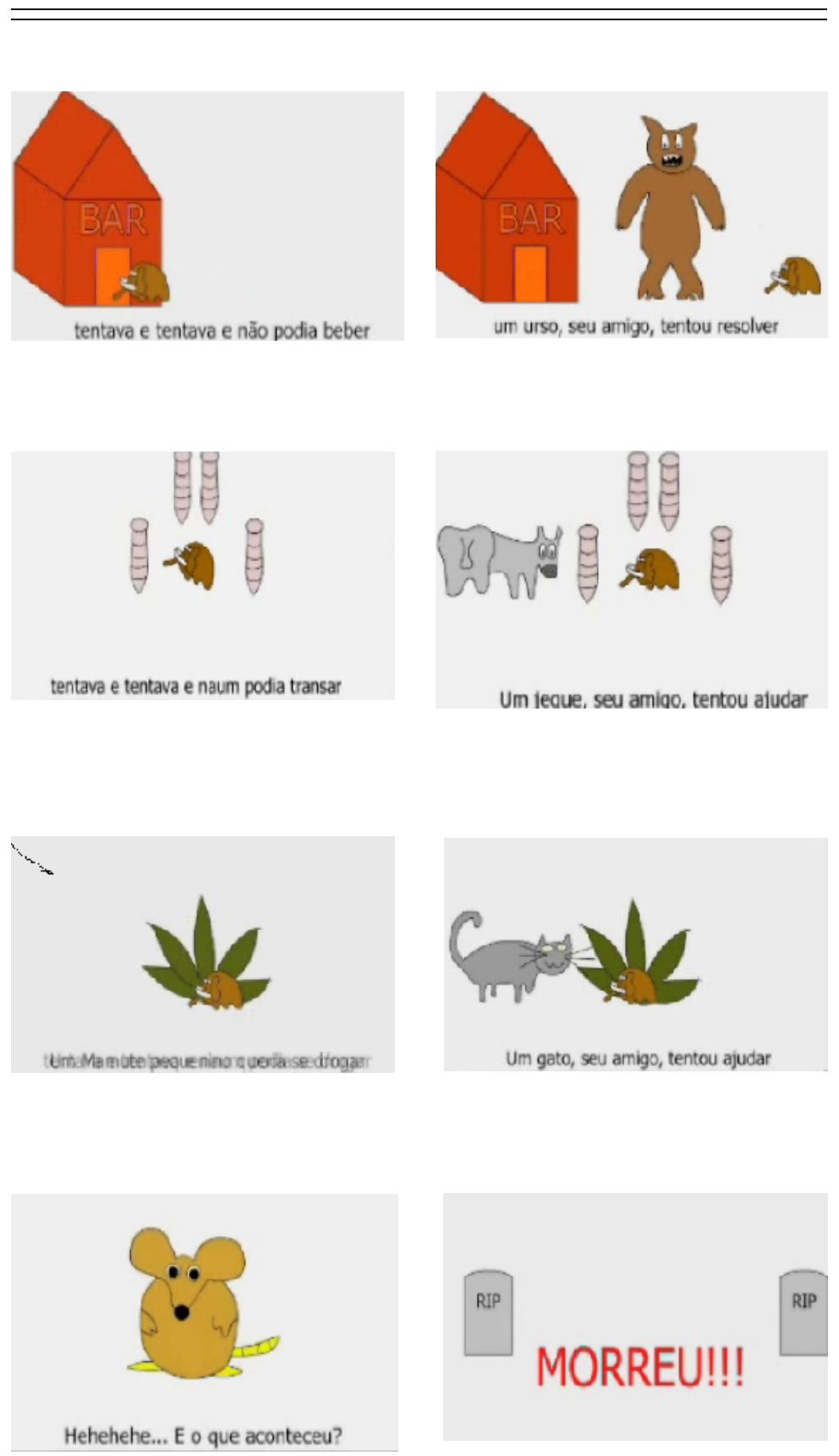
Em se tratando das imagens deste videoclipe, exemplificadas acima, sabe-se que elas foram construídas posteriormente à letra e à melodia, pois o autor (Rick) criou a animação bem depois da gravação da canção "História de um Mamute" (grupo Elbando, agosto 2004) e divulgada principalmente pela internet. Fica pressuposto, portanto, que a letra direcionou a criação das imagens, as quais não são abstratas e temáticas, mas concretas e figurativas, sendo fáceis de identificar e decodificar.

Dessa forma, como já explicitado, as figuras foram montadas visando, aparentemente, a reforçar os sentidos presentes no conteúdo do texto verbal, o qual possui um perfil pedagógico (passar valores morais e comportamentais aos jovens), pelo menos diante dos temas defendidos no seu interior. As imagens e as cores são recursos simbólicos, isto é, emitem sentidos construídos e sedimentados dentro de nossa cultura e sociedade (ex. o vermelho representa o perigo, o sangue, a doença e a sedução).

Percebe-se que esta animação foi construída em estilo de História em Quadrinho (imagens estáticas, divididas em partes iguais), gênero textual muito apreciado por crianças e adolescentes. Dessa maneira, os desenhos não se unificam, mas permanecem isolados uns dos outros. Este fator reforça o conteúdo verbal, dividido também em várias pequenas histórias, contendo um mesmo sujeito (mamute), um mesmo destinador (animal mais velho), uma mesma performance (entrar em conjunção com os vícios) e uma mesma sanção (danos à saúde do mamute). Tais histórias parecem representar os diferentes destinos dos adolescentes, figurativizados pelo mamute.

As estruturas estáticas e as figuras coloridas estão sobre um fundo muito branco e ganham destaque visual. Elas possuem formas bastante lineares, ou seja, o autor utilizou a plasticidade e planificação tátil (não apresentam profundidade), para compor os desenhos (lembra os traços e desenhos feitos por crianças, provavelmente o grande enunciatário imaginado pelo autor das figuras). Estes também são geralmente assimétricos, pois a figura do mamute é sempre menor que as demais imagens, colocadas ao 
seu lado, o que demonstra ser ele ainda um filhote e os outros animais adultos, pressupostamente, mais espertos. Os desenhos dos vícios são também maiores que o personagem principal, para demonstrar, talvez, a força destrutiva e mortal destes, que são mais fortes mesmo para um animal do porte do mamute.

As imagens estão posicionadas no centro da tela e de maneira frontal, o que desencadeia o olhar do espectador diretamente para a imagem, logo a sua frente, posicionando o enunciatário como um observador, o qual não está inserido na figura, mas se encontra à parte, do lado de fora (distanciamento). As figuras não abrangem todos os espaços da tela e evidenciam a objetividade racional, veiculando somente aquilo que é essencial; desvaloriza os significados supérfluos e os exageros em suas formas. As imagens dialogam com o discurso verbal, essencialmente formado pela debreagem enunciva (quer manter um distanciamento entre leitor e personagem).

As figuras possuem somente uma cor, ou seja, não apresentam sombreamentos. Assim tudo é distribuído de maneira muito "clara" e evidente, tanto na forma como no sentido, não havendo ambiguidade ou polissemia para quem olha as imagens. A mensagem imagética é bastante didática ou moralizante, até para as crianças pequenas, isto é, exercem uma função de facilitadoras da assimilação e memorização do conteúdo verbal (técnica muito usada na educação infantil). O sentido é veiculado diretamente, de maneira simples, objetiva, racional e concisa, o que possibilita uma compreensão rápida e fácil dos significados já explicitados na letra.

A partir desta pesquisa, nota-se que as imagens presentes no videoclipe estudado possuem características do "estilo clássico" (formas planas ou bidimensionais - sem profundidade, cores primárias, imagem centralizada e linhas retas), segundo as categorias, que definem o estilo clássico $\times$ barroco presentes na obra de $\mathrm{H}$. Wöllflin (apud FLOCH, 1986), "Princípios fundamentais da história da arte". Este estilo clássico salienta a objetividade e a racionalidade em um texto imagético, sendo menos emotivo/ passional e subjetivo que o estilo pictórico (barroco). 
O texto sempre mostra o mamute sem um chão, ele está flutuando, como se estivesse com a cabeça no "mundo da lua", desconectado do seu tempo, espaço e realidade que o cerca, divaga em seu mundo interior fantástico, onde tudo é possível. Pode-se inferir, diante das primeiras cenas, em que o mamute (animal ancestral) aparece sozinho, que ele estaria são e salvo, em seu habitat natural, pois ainda não havia entrado em conjunção com a cultura humana e seus vícios mortais. Já os animais domésticos (pomba, cachorro, jegue, ursos de pelúcia, gato) são aqueles seres do mundo natural, que já estariam integrados e contaminados pela cultura humana e por isso apresentam as características em sua personalidade aculturada: falsidade, traição, desonestidade e corrompimento. Estes também levam outros a negarem seu estado natural e a valorizarem e se envolverem com os maus hábitos humanos. Observa-se, aqui, a oposição semântica fundamental do texto imagético: natureza x cultura, em que o enunciatário defende o estado natural do mamute como sendo bom; garante sua vida. Tem-se, aqui, a intertextualidade com o pensamento de Rousseau, que diz que "o homem nasce bom, mas a sociedade o corrompe". A natureza semiotiza a virtude e a vida, já a cultura semiotiza a corrupção e a morte.

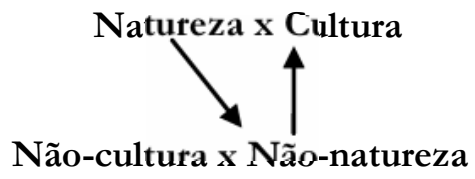

- Natureza $=$ virtude $($ representada pelas figuras do mamute) $=\mathrm{S} \cap$ Ov vida

- Cultura = vícios $($ representada pelas figuras do edifício, álcool, cigarros, prostitutas e cocaína) = S U Ov vida 
O primeiro desafio é uma aventura, tentar voar pulando do quinto andar de um prédio (cinza), sendo guiado por uma pomba maior também de cor cinza, representando algo nebuloso, obscuro e incerto. $\mathrm{O}$ segundo passo foi fumar quinhentos cigarrinhos cinza e enormes, unidos uns aos outros formando um grupo maior e mais poderoso que o pequeno mamute. Estes objetos foram ofertados por um cão igualmente cinza, bem mais alto que ele.

$\mathrm{E}$ assim seguem-se as demais cenas, contendo um bar vermelho com a porta fechada, que simboliza o perigo e um sinal de alerta; as bebidas alcoólicas são nocivas à saúde. O copo é grande e cinza, e o urso que o oferece é enorme e possui garras e dentes afiados (demonstra perigo e crueldade). O jegue "grande e cinza" como os outros, o entrega a cem prostitutas com cabelos amarelos, batons e vestidos vermelhos (sedução e perigo), seios à mostra $\mathrm{e}$ rostos idênticos, como se não fossem seres vivos, mas somente objetos como os demais produtos consumidos pelo mamute.

Nota-se que nas cenas onde se fala verbalmente das doenças, machucados e morte, ocasionadas pelos hábitos insalubres, não há imagens, deixando estas lacunas para o leitor preencher com sua criatividade e conhecimento de mundo. Talvez o autor não quisesse transmiti-las por meio de desenhos, que poderiam amenizar a gravidade destas síndromes.

Algumas cores predominam, do início ao fim, o cinza, o vermelho e o preto - os quais sempre sugerem o perigo, o sangue, a atenção, o desconhecido e o fatal. Esta representação acontece em nossa cultura ocidental. Outra cor bastante sugestiva é o roxo - da palavra overdose, que simboliza a morte.

Ao final aparecem os grandes pontos de interrogação, que sugerem a curiosidade geral de quem viu tantas aventuras ou desventuras do mamute. Neste momento, as cenas unidas à melodia promovem certo suspense, salientado por uma breve pausa melódica e verbal. A canção e as imagens, porém, satisfazem a curiosidade do espectador, logo a seguir, ao divulgar o terrível castigo do mamute (a morte). Já os vários pontos de exclamação denotam emoção, indignação e surpresa dos enunciatários, diante do triste e trágico fim do jovem mamute. 
As cenas finais são as mais marcantes, já que o pequeno mamute não aparece mais em cena, sendo substituído por túmulos cinza e a palavra morreu em preto. Visualiza-se, após este estudo, um nítido diálogo entre a oposição citada no nível fundamental linguístico: virtude $\mathrm{x}$ vícios com o eixo semântico do plano imagético (natureza x cultura). Um sujeito disfórico que deu seu maior Ov: a vida, em troca de outro OV menor e efêmero (aventuras destrutivas), provocadas pelos vícios culturais (destroem o corpo natural e saudável do mamute, que poderia ser virtuoso e manterse vivo em seu estado natural).

Os sentidos do código verbal e do código imagético são bastante sincrônicos e semelhantes, o que reforça o fazer persuasivo deste texto.

\section{O Contágio do Ouvinte por Meio da Sonoridade Musical}

História de um Mamute

\section{Reggae}

G

Em

Am

D7

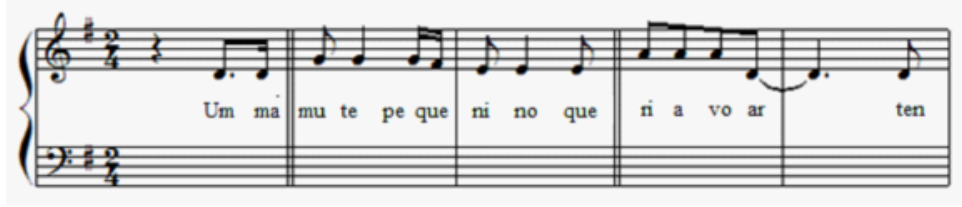

G

Em

Am

D7

G

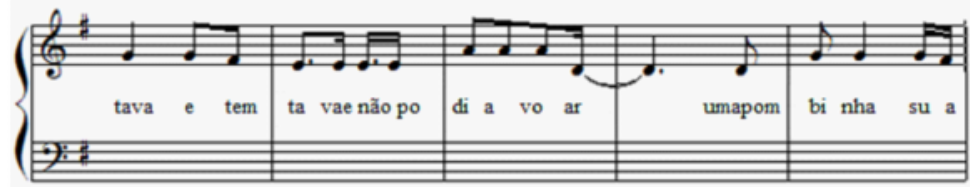



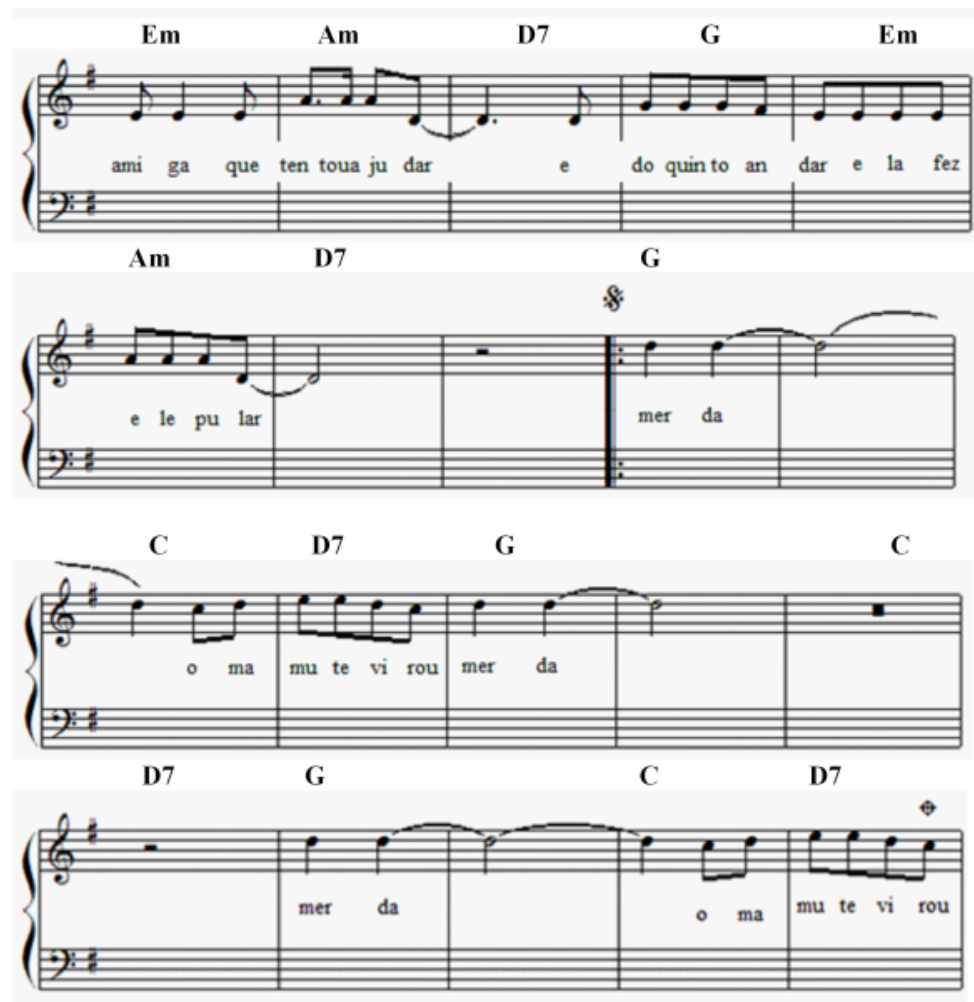

C

D7

G

Keity C. Seco Bruning

O plano sonoro-musical contagia, por meio de estímulos do sistema nervoso, os enunciatários a realizar exatamente as ações repudiadas pela letra e pelas imagens. Vejamos como ocorre a veiculação destes sentidos, pela análise mais apurada do campo musical, o qual pode persuadir o enunciatário de modo sutil e irrefletido, envolvendo de tal modo o ouvinte que este não atenta para as mensagens verbais, mas se embala e se diverte nas ondas sonoras. O enunciatário torna-se um não sujeito, segundo Coquet, posto que realiza ações de modo programado e não pensado. 
Diante do exposto, percebe-se a força argumentativa do plano sonoro, que contagia o ouvinte, chegando até a levá-lo a fazer o que não quer ou gosta racionalmente (ex. cantamos, muitas vezes, uma canção de que não gostamos). Nota-se que os sentidos presentes no conteúdo da mensagem linguística parecem que são, frequentemente, ignorados pelo sujeito reflexivo, já que a leitura do verbal exige concentração, atenção e exercício cognitivo por parte do narratário musical.

O plano sonoro da canção História de um Mamute apresenta inicialmente o bramido de alguns elefantes, logo em seguida vem a introdução da canção, com sons de instrumentos musicais e posteriormente entra a voz do cantor. A intertextualidade entre o som e as imagens é nítida, neste trecho: natureza (som dos elefantes e imagem do mamute sozinho) x cultura (início do som produzido por instrumentos musicais e pela voz humana, acompanhados das imagens dos outros animais e depois dos vícios).

O som melódico cantado é interrompido por um som falado - O que aconteceu? - que denota o domínio da fala, com sua entonação típica, sobre o canto. Este estilo é denominado de Figurativização, que remete o discurso musical para um momento enunciativo (debreagem enunciativa), isto é, é um momento dialógico, aparentemente real entre o enunciador e o enunciatário (ambos parecem estar aqui e agora numa conversa informal). Dessa forma instaura-se uma proximidade sonoro-enunciativa entre o ouvinte e o cantor, tornando o texto mais verdadeiro e persuasivo (narrador e ouvinte conversando pessoalmente).

Apesar dessas interferências faladas, a canção pode ser dividida em duas partes primordiais, a primeira etapa (até o compasso 18) pode ser caracterizada como Passional, já que as marcas textuais revelam uma constituição mais emotiva. Os aspectos desta etapa são: andamento lento (desaceleração/ tranquilidade), acordes menores e melancólicos (Em e Am), acompanhamento rítmico em Reggae (ligado ao sossego), suavidade na execução musical, notas mais graves e introspectivas (diferente das fortes emoções suscitadas pelas notas mais agudas), som vocal em solo (solidão). 
A melodia também apresenta outras marcas interessantes, como um desenho melódico mais variado que a segunda parte, contendo diversos saltos intervalares (ex. ré para sol, mi para lá). Esses intervalos têm em média 2 tons e meio de distância, o que salienta bastante a diferença de altura e a dicotomia entre as ondas sonoras. Tal diferença e distanciamento entre os sons são perceptíveis pelo ouvido humano, o que remete aos sentimentos de solidão, angústia, disforia e um sentimento de disjunção entre o sujeito e seu OV (sons distantes e sujeitos distantes). Tal afirmação pauta-se em leis físicas, pois as diferentes alturas, reforçadas pela desaceleração do andamento, desencadeiam determinada reação somática, que sente o choque emitido por diferentes alturas de sonoridades. Essas percepções sensoriais são muito exploradas pelas canções com letras amorosas que, geralmente, salientam a separação corporal entre duas pessoas por meio da dicotomia das notas musicais, sentidas pelo homem. Por tudo isso, este estilo é denominado de Passional, utilizado como estratégia argumentativa sonora, que auxilia o plano verbal a descrever os estados passionais de um sujeito, que geralmente está em disjunção de seu Ov, como no caso do mamute (S U Ov aventura/êxtase).

Existe, neste trecho, a intersemioticidade entre a letra e a melodia, já que a letra enfatiza o sentimento de disforia (tristeza e angústia) do mamute, que está ainda longe de seu objeto valorizado (fortes emoções e aventuras). Vale lembrar que a melodia também é constituída de um vai-e-vem sonoro (ré, sol, mi, lá, re, sol, mi etc.), que complementam os significados verbais e retratam as tentativas - tentava e tentava e não sabia voar - do mamute em busca de seu OV.

A segunda fase (compasso 19 até o final) é a mais enfatizada pelo enunciador, que repete verbalmente as consequências destruidoras resultantes das performances realizadas pelo sujeito mamute. O som auxilia na repetição do refrão linguístico da seguinte forma: intensidade (mais força na execução musical), ausência de acordes menores e predomínio dos maiores (mais eufóricos que os menores), aceleração no andamento (estimula o movimento corporal), coro vocal (união e sincronia de vozes), notas 
mais agudas e vibrantes (mostra a tensão corporal do sujeito que canta tal nota), desenho melódico mais curto (objetivismo), notas encadeadas em duas sequências melódicas, uma descendente e duas ascendentes, divididas por intervalos curtos (meio tom ou um tom).

Geralmente tais sequências sonoras descrevem a conjunção de um sujeito com seu OV, e mostram uma dissonância significativa, neste trecho, entre os aspectos verbais e os sonoros. O verbal relata a sanção do sujeito mamute, punido pela conjunção com os hábitos humanos e culturais, já a melodia semiotiza a conjunção de um sujeito sonoro com seu Ov. Isto também pode ser visto pela nota sol (uma oitava acima), a mais aguda da melodia, entoada em estilo grand finale. A conclusão sonora com a nota sol, denominada nota tônica, indica a solução e resolução sonora para uma cadeia harmônica e também melódica, o que reforça o sentimento de realização e plenitude.

As músicas ou canções terminadas por este tipo de sonoridade (nota tônica aguda e longa), no final, levam o ouvinte a sentir-se eufórico sendo, portanto, um som carregado de entusiasmo, por parte do cantor e do ouvinte.

Importa ainda destacar que a aceleração sonora desta parte, unida aos intervalos curtos, faz com que o sistema nervoso do enunciatário não perceba as diferenças das ondas sonoras, fato que o leva a ouvir e a cantar uma música de modo mais empolgante, já que as diferenças ou dissonâncias são camufladas pela alta aceleração e pela ausência de intervalos longos. Este estilo sonoro é denominado por Tatit de Tematização. O corpo, quando ouve tais sonoridades, tende a ser estimulado a uma ação, geralmente em conjunto com outras pessoas. Citamos como exemplos as canções predominantemente somáticas e temáticas, como as canções de carnaval (levam a ação de cantar, pular em grupo), as músicas de academias de ginástica (dancing), que estimulam o exercício físico, as canções funks (estimulam o corpo a se mexer sensualmente), entre outros.

Ao comparar as duas fases musicais, percebe-se que o primeiro trecho (desacelerado e passional) dialoga com os demais planos de expressão e reforça os sentimentos de compaixão pelo 
ingênuo mamute. Já o segundo trecho, muito somático e eufórico, contagia o ouvinte a sentir alegria diante das tragédias vivenciadas pelo sujeito (virou merda, teve câncer, cirrose, AIDS, tomou uma overdose e morreu). Todas estas ações são cantadas de modo eufórico, estimulando os ouvintes a cantar, dançar e pular coletivamente (junto com o enunciatário) diante da desgraça alheia.

Essas afirmações foram comparadas e podem ser comprovadas por meio de uma observação prática, ou seja, por alguns significados veiculados pelo contexto. Os jovens que escutavam tal canção, no auge de seu sucesso (2005), não se interessavam pelos sentidos do conteúdo verbal. A parte verbal era cantada, mas não refletida, ou melhor, era ignorada e banalizada diante dos apelos e contágios instintivos da música. Desse modo, os jovens não atentavam para o drama vivido pelo mamute; eram contagiados, de forma alienante, pelo ritmo pulsante e alegre do rock (movimento predominante nesta parte). Eles tornavam-se não sujeitos (somáticos) que não pensam sobre o que ouvem ou fazem, sendo programados e manipulados a fazer algo de modo automático e mecânico.

Dessa forma, os sentidos das palavras merda (figura de fraturado), overdose, cirrose, Aids e até morte mudaram de conotação, isto é, ao invés de persuadir o enunciatário a se compadecer do drama alheio e aprender uma "lição" de moral, este trecho melódico torna o texto verbal cômico e divertido. Esta euforia débil e coletiva (coro das vozes) é ocasionada pela sensação de sincronia entre as diferenças sonoras, pois os pequenos intervalos, as repetições de notas e a desaceleração mascaram as divergências entre os sons; $\mathrm{o}$ ouvido percebe praticamente a mesma nota musical. O corpo fica, então, mais estimulado e eufórico, diante da aparente consonância e unidade do som.

A aparente preocupação do enunciador do videoclipe, que era ensinar o perigo dos vícios aos jovens, construindo um ethos de pai, professor, amigo da família e defensor da moral e das virtudes dos jovens é, visivelmente, modificada pela melodia. Esta mostra o ser do sujeito enunciador (manipulador), que acabou por motivar os jovens a realizarem as ações censuradas pela letra, já que tais 
ações tornam-se agora, diante desta sonoridade, inofensivas, engraçadas e até empolgantes.

Assim, parece que a letra alertou e ensinou o jovem a ter determinadas posturas, para não prejudicar sua saúde, porém a melodia banalizou e menosprezou as performances descritas verbalmente. A letra sanciona negativamente o sujeito mamute, já a melodia premia tais ações. Fica pressuposto, pela melodia, que o mamute morreu feliz, posto que faleceu em conjunção com seu Ov: aventura e fortes emoções.

O enunciador mostra seu ser mais individualista, preocupado mais em distrair, alegrar e divertir o jovem que consumirá o seu produto (CDs, shows, etc.). Se, por acaso, o sujeito enunciador mantivesse o mesmo estilo Passional e desacelerado, do início da canção, talvez o som ficasse muito melancólico, deprimente e até cansativo para o público-alvo. Pode-se inferir que o público pudesse repudiar uma canção menos acelerada, que estimulasse mais o pensar e o sentir (altruísmo e compaixão) do ouvinte.

Mostram-se logo abaixo, as oposições fundamentais presentes nos três diferentes códigos e, destacam-se concomitantemente, suas respectivas ideologias axiomáticas (em negrito):

Plano de expressão verbal: virtude $\mathrm{x}$ vícios

Plano de expressão imagético: natureza x cultura

Plano de expressão sonoro-musical: desencanto x êxtase

Importa, assim, enfatizar o poder argumentativo e persuasivo do plano sonoro, que contagia os seres humanos de modo tão prazeroso quanto imperceptível.

\section{Conclusão}

É cada vez mais evidente que as escolas brasileiras necessitam urgentemente ter acesso aos novos encaminhamentos metodológicos, voltados também ao ensino-aprendizado de textos multimidiáticos, como o videoclipe. Desse modo, análises como 
esta, podem contribuir, mesmo com uma pequena parcela, para a propagação do multiletramento escolar. Segundo Gada (2004, p. 43), "o universo de exploração que estes textos proporcionam é muito amplo, porém acredito que seu uso é ainda muito limitado".

Por conseguinte, pretende-se, com este trabalho, auxiliar tanto educadores quanto alunos a interagir, de modo crítico e reflexivo, em um mundo cada vez mais global e multicultural.

\section{Referências}

BARROS, Diana L. P. Teoria semiótica do texto. São Paulo: Ática, 2003.

BERTRAND, Denis. Caminhos da semiótica literária. São Paulo: EDUSC, 2003.

DIETRICH, Peter. Araçá Azul: uma análise semiótica. 2003. Dissertação (Mestrado em Linguística) - Universidade de São Paulo, São Paulo.

FLOCH, Jean-Marie. Les formes de 1'empreite. Perigueux: Pierre Fanlac, 1986.

GADA, Ana Lúcia C. A letra de música no livro didático de língua portuguesa. Máthesis, Jandaia do Sul, v. 5, n. 1, p. 43-64, 2004.

GREIMAS, Algirdas Julien.; FONTANILLE, Jacques. Semiótica das Paixões. São Paulo: Editora Ática, 1993.

TATIT, Luiz. Musicando a semiótica. Ensaios. São Paulo: Annablume, 1998.

O cancionista: composição de canções no Brasil. São

Paulo: Edusp, 2002.

HISTÓRIA DE UM MAMUTE. Disponível em: <http:// www.ochent.com.br/maurilio/mamute/Mamute_Portugues.htm>. Acesso em: 20 ago. 2009. 
WISNIK, José Miguel. O som e o sentido: uma outra história das músicas. São Paulo: Companhia das Letras, 2006. 